\title{
UJI EFEK ANALGETIK NANOPARTIKEL EKSTRAK RIMPANG JAHE MERAH (Zingiber officinale var Rubrum) PADA TIKUS PUTIH JANTAN GALUR WISTAR (Rattus norvegicus)
}

\author{
Christian Excelino Kaunang ${ }^{1)}$, Widdhi Bodhi ${ }^{1)}$, Hosea Jaya Edy ${ }^{1)}$ \\ ${ }^{1)}$ Program Studi Farmasi FMIPA UNSRAT Manado, 95115
}

\begin{abstract}
Red Ginger (Zingiber officinale var rubrum) has long been known that its properties can cure various diseases. Chemical components such as gingerol, shogaol, and zigeron that can provide pharmacological and physiological effects such as analgesic, antioxidant, carcinogenic, and non-mutagenic effects even at high concentrations. This study aims to determine whether the nanoparticles of red ginger rhizome extracts can provide analgesic effects in white male wistar rats (Rattus norvegicus). The red ginger rhizome was extracted using maceration method with ethanol as a solvent and nanoparticle formulation of red ginger extract was made using an ionic gelation method. The test mice animals were divided into 5 kinds of treatments and each treatment performed 3 repetitions. Test of the analgesic effect was carried out by the method of thermic induction using waterbath and was observed as many as 5 times, namely before giving test material, the $30^{\text {th }}$ minute, $60^{\text {th }}$ minute, $90^{\text {th }}$ minute, and $120^{\text {th }}$ minute. Group I as negative control was given $1 \%$ CMC, group II as positive control was given paracetamol, group III-V was treated using nanoparticles red ginger extract with multilevel doses of $0.0215 \mathrm{~g}, 0.043 \mathrm{~g}$, and $0.086 \mathrm{~g}$. Based on the ANOVA test, the results obtained of analgesic effects significantly different with $p=0.019(p<0.05)$.
\end{abstract}

Keywords: analgesic, nanoparticles, red ginger.

\begin{abstract}
ABSTRAK
Jahe merah (Zingiber officinale var rubrum) sudah lama diketahui khasiatnya yaitu dapat menyembuhkan berbagai macam penyakit. Komponen kimia seperti gingerol, shogaol, dan zigeron yang dapat memberikan efek farmakologi maupun efek fisiologi seperti efek analgetik, antioksidan, karsinogenik, dan non mutagenik meskipun pada konsentrasi yang tinggi. Penelitian ini bertujuan untuk mengetahui apakah nanopartikel ekstrak rimpang jahe merah dapat memberikan efek analgetik pada tikus putih jantan galur wistar (Rattus norvegicus). Rimpang jahe merah diekstraksi menggunakan metode maserasi dengan etanol sebagai pelarut dan dibuat formulasi nanopartikel ekstrak rimpang jahe merah dengan metode gelasi ionik. Hewan uji tikus dibagi menjadi 5 macam perlakuan setiap perlakuan dilakukan 3 kali pengulangan. Untuk pengujian efek analgetik dilakukan dengan metode induksi termik menggunakan waterbath dan dilakukan pengamatan sebanyak 5 kali yaitu sebelum pemberian bahan uji, menit ke-30, menit ke-60, menit ke-90, dan menit ke-120. Kelompok I sebagai kontrol negatif diberi CMC 1\%, kelompok II sebagai kontrol positif diberi parasetamol, kelompok III-V diberi perlakuan menggunakan nanopartikel ekstrak rimpang jahe merah dengan dosis yang bertingkat yaitu 0,0215g, 0,043g, dan 0,086g. Berdasarkan hasil uji ANOVA didapatkan efek analgetik yang berbeda secara bermakna dengan $p=0,019(p<0,05)$.
\end{abstract}

Kata Kunci: Jahe merah, analgetik, nanopartikel. 


\section{PENDAHULUAN}

Nanopartikel merupakan partikel koloid padat dengan diameter 1-1000 nm (Tiyaboonchai, 2003). Nanopartikel bertujuan untuk mengatasi kelarutan zat aktif yang sukar larut, memperbaiki bioavailabilitas yang buruk, memodifikasi sistem penghantaran obat sehingga obat dapat langsung menuju daerah yang spesifik, meningkatkan stabilitas zat aktif dari degradasi lingkungan (penguraian enzimatis, oksidasi, hidrolisis), memperbaiki absorbsi suatu senyawa makromolekul, dan mengurangi efek iritasi zat aktif pada saluran cerna (Mohanraj dan Chen, 2006).

Jahe merah (Zingiber officinale var rubrum) sudah lama diketahui khasiatnya yaitu dapat menyembuhkan berbagai macam penyakit, dibandingkan dengan jahe gajah dan jahe emprit. Meskipun demikian, kebanyakan orang umumnya lebih mengenal jahe gajah yang berguna sebagai bumbu dapur, rempahrempah, dan bahan obat-obatan. Berdasarkan penelitian para ahli dalam negeri maupun para ahli dari luar negeri, jahe memiliki efek farmakologis yang berkhasiat sebagai obat dan mampu memperkuat khasiat obat yang dicampurkannya (Tim Lentera, 2002).

Jahe memiliki beberapa komponen kimia seperti gingerol, shogaol, dan zigeron yang dapat memberikan efek farmakologi maupun efek fisiologi seperti efek analgetik , antioksidan, karsinogenik, dan non mutagenik meskipun pada konsentrasi yang tinggi (Hernani dan Winarti, 2011). Menurut penelitian Dugasani et al (2010), kandungan gingerol yang ada pada jahe merah lebih tinggi dibanding jahe lainnya. Senyawa aktif pada jahe merah adalah [6]-gingerol dan 3R,5S-[6] gingerdiol.

\section{METODOLOGI PENELITIAN}

\section{Waktu dan Tempat Penelitian}

Penelitian ini akan dilaksanakan pada bulan Mei - September 2019 di Laboratorium Advance Program Studi Farmasi Fakultas Matematika dan Ilmu Pengetahuan Alam Universitas Sam Ratulangi.

\section{Alat}

Alat yang akan digunakan dalam penelitian ini antaralain : alat-alat gelas (pyrex), blender, oven, pisau, timbangan analitik, tisu, wadah, kandang pemeliharaan hewan, sarung tangan, tempat air minum dan makanan hewan, sudip, kertas saring, lumpang dan alu, stopwatch, disposable syringe $3 \mathrm{~mL}$, dan NGT (Nasograstric Tube) No. 3,5, aluminium foil, dan Waterbath.

\section{Bahan}

Bahan yang digunakan adalah : jahe merah, tablet parasetamol $500 \mathrm{mg}$, makanan hewan uji, CMC 1\%, etanol 96\%, Natpp, kitosan, polisorbat 80 , poldan akuades. 


\section{Hewan Uji}

Objek yang digunakan dalam penelitian ini adalah tikus putih jantan yang berumur 5 minggu dan berat 100-200 gram dengan jumlah 15 ekor. Setelah itu diadaptasi selama 10 hari.

\section{Rancangan Penelitian}

Penelitian ini menggunakan rancangan penelitian eksperimental laboratorium dengan menggunakan tikus putih jantan sebagai hewan percobaan. Perlakuan dibagi dalam 5 kelompok, dalam kelompok masing-masing terdiri dari 3 ekor tikus putih jantan yang sudah diadaptasikan terlebih dahulu terhadap lingkungan selama 10 hari.

Pembagian kelompok perlakuan sebagai berikut :
K (-) : diberikan suspensi CMC $1 \%$ sebanyak $1 \mathrm{~mL}$
$\mathrm{K}(+)$ : diberikan suspensi parasetamol dosis $0,132 \mathrm{~g}$

KP1 : diberikan suspensi nanopartikel ekstrak jahe merah $0,0215 \mathrm{~g}$

KP2 : diberikan suspensi nanopartikel ekstrak jahe merah $0,043 \mathrm{~g}$

KP3 : diberikan suspensi nanopartikel ekstrak jahe merah 0,086 g

\section{Pembuatan Simplisia dan Proses Ekstraksi}

Sampel rimpang jahe merah sebanyak 6500 g dicuci dengan air mengalir, dikupas, diiris tipis, dikeringkan dengan cara diangin anginkan sampai menghasilkan sampel kering, lalu ditimbang menghasilkan berat kering $1250 \mathrm{~g}$ kemudian diblender hingga halus dan diayak menggunakan pengayak. Serbuk rimpang jahe merah ditimbang sebanyak $400 \mathrm{~g}$, dimasukkan ke dalam wadah, kemudian ditambahkan pelarut etanol 96\% sebanyak $2000 \mathrm{~mL}$, ditutup dan dibiarkan selama 5 hari terlindung dari cahaya matahari. Setelah 5 hari, rendaman tersebut disaring dengan menggunakan kertas saring (filtrat 1) dan sisanya diekstrak kembali dengan etanol sebanyak 1200mL selama 2 hari. Filtrat 1 dan filtrat 2 digabung kemudian diuapkan dengan menggunakan evaporator pada suhu $40^{\circ} \mathrm{C}$ yang bertujuan untuk menguapkan pelarutnya higga berupa endapan tidak terlalu kental. Proses dilanjutkan dengan pemekatan ekstrak sampai menjadi ekstrak kental dengan menggunakan oven pada suhu $40^{\circ} \mathrm{C}$. Hasil ekstrak kental didapat sebanyak 24,2 g.

\section{Pembuatan Larutan CMC 1\%}

Sebanyak 1 gram CMC ditaburkan dalam beaker glass yang berisis $10 \mathrm{~mL}$ aquades yang telah dipanaskan, aduk sampai mengembang kemudian dihaluskan sampai homogen. Selanjutnya dimasukkan ke dalam labu ukur dan tambahkan aquades sampai volume $100 \mathrm{~mL}$. 


\section{Preparasi Nanopartikel Ekstrak Rimpang}

Jahe Merah

\section{Pembuatan Laruan Kitosan}

Kitosan ditimbang sebanyak 0,5 gram kemudian dimasukkan ke dalam gelas kimia dan ditambahkan akuades sebanyak $100 \mathrm{~mL}$. Kemudian dilarutkan dengan polisorbat 80 sebanyak $1 \mathrm{~mL}$ dan diaduk dengan menggunakan magnetic stirrer pada hotplate higga larut.

\section{Penyiapan Nanopartikel Ekstrak Rimpang}

Jahe Merah

Sebanyak 0,0215 g, 0,043 g, dan 0,086

g ekstrak rimpang jahe merah ditimbang dan dilarutkan dalam etanol $96 \%$ sebanyak $5 \mathrm{~mL}$. Lalu dilakukan sonikasi selama 5 menit.

\section{Pembuatan Nanopartikel Ekstrak}

Rimpang Jahe Merah

Larutan kitosan sebanyak $100 \mathrm{~mL}$ ditambahkan polisorbat 80 sebanyak $1 \mathrm{~mL}$ dan diaduk dengan menggunakan magnetic stirrer pada hotplate selama 10 menit. Setelah itu pada larutan kitosan dimasukkan 0,0215 g, 0,043 g, dan 0,086 g ekstrak rimpang jahe merah dan diaduk menggunakan magnetic stirrer pada hotplate selama 30 menit. Setelah itu ditambahkan larutan TPP 0,1 gram sebanyak $20 \mathrm{~mL}$ lalu diaduk menggunakan magnetic stirrer pada hotplate selama 90 menit.

\section{Pemberian Suspensi Nanopartikel dan Larutan Pembanding}

\section{Nanopartikel Rimpang Jahe Merah}

Takaran dosis untuk manusia dengan berat badan $70 \mathrm{~kg}$ pada tikus dengan berat badan 200 gram adalah 0,018. Rata-rata orang Indonesia beratnya $50 \mathrm{~kg}$. Dosis pemakaian jahe merah pada manusia dewasa $(50 \mathrm{~kg})$ yang biasa digunakan masyarakat adalah $15 \mathrm{~g}$ (Tim Lentera, 2002).

$=(70 \mathrm{~kg} / 50 \mathrm{~kg} \times 15 \mathrm{~g}) \times 0,018$

$=0,238 \times 0,0018$

$=0,0043$ gram $/ 200$ gramBB tikus

Dalam percobaan digunakan dosis nanopartikel jahe merah yang bertingkat :

Kelompok Perlakuan $1=0,5 \times 0,0043 \mathrm{~g}=$ $0,00215 \mathrm{~g}$

Kelompok Perlakuan $2=1 \times 0,0043 \mathrm{~g}=$ $0,0043 \mathrm{~g}$

Kelompok Perlakuan $3=2 \times 0,0043 \mathrm{~g}=$ $0,0086 \mathrm{~g}$

\section{Kontrol Positif}

Tiap tablet parasetamol mengandung 500 mg. Takaran konversi dosis parasetamol untuk manusia dengan berat badan $70 \mathrm{~kg}$ pada tikus dengan berat badan $200 \mathrm{~g}$ adalah 0,018. Rata-rata orang Indonesia beratnya $50 \mathrm{~kg}$, maka dosis untuk tikus adalah :

$=(70 / 50 \times 500 \mathrm{mg}) \times 0,018$

$=12,6 \mathrm{mg} / 200 \mathrm{~g}$ tikus 


\section{Metode Induksi Nyeri Cara Termik}

Uji efek analgetik menggunakan metode induksi nyeri dengan cara termik yaitu dengan cara memasukkan tikus ke dalam beaker glass yang telah dipanaskan dalam waterbath pada suhu $55^{\circ} \mathrm{C}$ sebagai stimulus nyeri dan tikus akan memberikan respon dalam bentuk menjilat kaki dan melompat. Sebagai patokan, bahwa tikus mulai merasakan nyeri pada waktu menjilat kaki belakang dan melompat, karena menjilat kaki depan adalah hal normal bagi tikus (Turner, 1965).

\section{Pengujian Efektivitas Analgetik}

Langkah-langkah pengujian efek analgetik pada hewan uji ialah sebagai berikut

a. Beaker glass dimasukkan ke dalam waterbath yang berisi air, kemudian waterbath dipanaskan hingga suhu $55^{\circ} \mathrm{C}$. Setelah suhu mencapai $55^{\circ} \mathrm{C}$, tikus dimasukkan ke dalam beaker glass tersebut.

b. Setelah tikus ada di dalam beaker glass maka responnya diamati, yaitu berupa gerakan menjilat kaki dan melompat. Pengamatan dilakukan selama 1 menit.

c. Kelompok kontrol negatif diberikan CMC $1 \%$, kelompok kontrol positif diberikan parasetamol dan kelompok perlakuan diberikan nanopartikel jahe merah. Tikus lalu diistirahatkan untuk diamati kembali pada menit ke-30. d. Pengamatan dilakukan hingga menit ke120, dengan interval waktu 30 menit untuk setiap pengamatan.

e. Pengamatan dilakukan sebanyak 5 kali, yaitu :

1. Sebelum pemberian bahan uji

2. Menit ke-30

3. Menit ke-60

4. Menit ke-90

5. Menit ke-120

\section{Analisis Data}

Data hasil pengamatan dikumpulkan dan disajikan dalam bentuk tabel, grafik dan analisis statistik menggunakan uji One-Way ANOVA (Analysis of Variance) untuk mengetahui pengaruh eksktrak nanopartikel rimpang jahe merah (Zingiber officinale Roxb) terhadap tikus putih galur wistar (Rattus norvegicus) dan menggunakan Least Significant Difference (LSD) untuk menguji signifikasi dari perbedaan rata-rata antar kelompok perlakuan.

\section{HASIL DAN PEMBAHASAN}

\section{Hasil Penurunan Respon Tikus}

Hasil rata-rata penurunan respon tikus (jilatan dan lompatan) terhadap kontrol negatif, kontrol positif dan ekstrak nanopartikel rimpang jahe merah dapat dilihat sebagai berikut : 
Tabel 1. Hasil rata-rata penurunan respon tikus sebelum dan sesudah pemberian bahan uji :

\begin{tabular}{lccccc}
\hline Kelompok & Sebelum & \multicolumn{4}{c}{ Sesudah Pemberian Bahan Uji } \\
\cline { 3 - 6 } Perlakuan & Pemberian & Menit & Menit & Menit & Menit \\
\cline { 3 - 6 } Bahan Uji & ke -30 & ke -60 & ke -90 & ke - 120 \\
\hline Kontrol & 13,6 & 10,6 & 11,6 & 10,3 & 12,6 \\
Negatif & & & & & \\
Kontrol & 9,6 & 5 & 0 & 0 & 0 \\
Positif & & & & & \\
KP1 & 8 & 7 & 3,3 & 0 & 0 \\
KP2 & 12,6 & 1 & 0 & 0 & 0 \\
KP3 & 13,6 & 0,6 & 0 & 0 & 0 \\
\hline
\end{tabular}

Keterangan Tabel 1 :

$\mathrm{K}(-) \quad$ : Kelompok kontrol negatif (CMC 1\%) sebanyak $1 \mathrm{~mL}$

$\mathrm{K}(+) \quad$ : Kelompok kontrol positif (suspensi parasetamol) dosis $0,132 \mathrm{~g}$

KP1 : Kelompok perlakuan ekstrak nanopartikel rimpang jahe merah dosis $0,0215 \mathrm{~g}$

KP2 : Kelompok perlakuan ekstrak nanopartikel rimpang jahe merah dosis $0,043 \mathrm{~g}$

KP3 : Kelompok perlakuan ekstrak nanoparikel rimpang jahe merah dosis $0,086 \mathrm{~g}$

\section{Hasil Uji Dengan One-Way ANOVA}

Tabel 2. Hasil Uji ANOVA

\begin{tabular}{cccccc}
\hline & Sum of Squares & df & Mean Square & F & Sig. \\
\hline Between Grougs & 305,814 & 4 & 76,453 & 3,759 & 019 \\
Wittin Groups & 406,792 & 20 & 20,340 & & \\
Total & 712,605 & 24 & & & \\
\hline
\end{tabular}

Uji ANOVA dilakukan pada kelima kelompok perlakuan. Hasil analisis menunjukkan nilai $\mathrm{p}=0,019(\mathrm{p}<0,05)$.

Tikus putih jantan galur wistar yang berumur 2-3 bulan dengan berat badan 100200 gram digunakan sebagai hewan uji dikarenakan menurut Hakim (2002) tikus putih jantan galur wistar memiliki kemiripan dengan manusia dalam hal fisiologi, anatomi, patologi dan metabolisme. Berbeda dengan tikus betina, tikus jantan digunakan karena memiliki kecepatan metabolisme yang tidak terpengaruh oleh perubahan hormonal dibandingkan dengan tikus betina, karena tikus betina mengalami siklus uterus masa kehamilan dan menyusui. Sebelum perlakuan, tikus dipuasakan terlebih dahulu selama 6 jam, hal ini dilakukan untuk mengosongkan lambung tikus agar tidak terjadi reaksi antara makanan tikus dan zat uji yang akan diberikan.

Penelitian ini dilakukan untuk mengetahui ada tidaknya efek analgetik dari nanopartikel ekstrak rimpang jahe merah dengan menggunakan metode induksi termik yang diuji pada tikus putih galur wistar. Stimulus nyeri yang diberikan pada hewan uji yaitu berupa rangsangan panas dengan suhu $55^{\circ} \mathrm{C}$. Menurut Guyton 1994, seseorang mulai merasakan sakit pada suhu $45^{\circ} \mathrm{C}$ dan reseptor panas mempunyai respon terhadap suhu $30-45^{\circ} \mathrm{C}$, suhu diatas $45^{\circ} \mathrm{C}$ mulai terjadi kerusakan jaringan yang diakibatkan oleh 
panas dan sensasinya berubah menjadi nyeri. Jadi, rasa nyeri yang disebabkan oleh panas sangat erat hubungannya dengan kemampuan panas untuk merusakan jaringan. Gerakan menjilat kaki atau melompat dinilai sebagai respon tikus sebagai patokan bahwa tikus mulai merasakan nyeri pada waktu menjilat kaki belakang atau melompat.

Pembuatan nanopartikel ekstrak rimpang jahe merah dibuat dengan metode gelasi ionik. Metode gelasi ionik ini didasarkan pada interaksi elektrostastik antara grup amina kitosan dan grup muatan negatif polianion, polianion yang digunakan adalah natrium tripolifosfat (Na-TPP). Nanopartikel dengan reaksi gelasi ionik mempunyai keuntungan yaitu tidak memerlukan pemanasan sehingga kemungkinan rusak senyawa aktif bisa dihindarkan. Penambahan polisorbat 80 pada larutan kitosan $0,5 \%$ berfungsi untuk menstabilkan emulsi partikel dalam larutan dengan cara mencegah timbulnya penggumpalan, serta memperkecil ukuran partikel. Peningkatan kecepatan pengadukan dari $1000 \mathrm{rpm}$ ke $1500 \mathrm{rpm}$ pada saat proses pembuatan nanopartikel ekstrak rimpang jahe merah bertujuan untuk memperkecil ukuran partikel, karena semakin cepat proses pengadukan maka semakin kecil ukuran partikel yang akan diperoleh.

Pada penelitian ini digunakan kitosan $0,5 \%$ dan Na-TPP $0,1 \%$, dengan rasio $5: 1$ antara berat kitosan dan natrium tripolifosfat sehingga dapat menghasilkan nanopartikel dengan ukuran yang lebih kecil, serta menghasilkan efisiensi penyerapan paling baik dengan struktur nanopartikel (Zhang, 2004). Mekanisme terbentuknya nanopartikel ekstrak rimpang jahe merah ini didasarkan pada interaksi elektrostatik antara gugus amina dari kitosan $0,5 \%$ dan muatan negatif dari polianion natrium tripolifosfat $0,1 \%$ sehingga membentuk nanopartikel secara spontan ketika saat pengadukan menggunakan magnetic stirrer (Sailaja et al, 2010).

Pada kelompok kontrol negatif yang diberikan $\mathrm{CMC} 1 \%$ menunjukkan rata-rata jumlah respon tikus antara sebelum dan sesudah 30 menit pemberian CMC 1\%, terjadi penurunan, Walaupun pada menit ke-60, menit ke-90, dan menit ke-120 terjadi naik turun respon nyeri pada tikus. Hal ini disebabkan karena pada kontrol negatif yaitu CMC 1\% tidak terkandung zat aktif yang dapat mengurangi nyeri sehingga rasa nyeri pada tikus tidak menurun.

Pada penelitian ini digunakan parasetamol sebagai kontrol positif karena paresetamol sudah terbukti memiliki efek analgetik dan menjadi pilihan utama oleh masyarakat Indonesia. Pada kelompok kontrol positif yaitu parasetamol, menunjukkan terjadi respon rata-rata hewan uji terhadap rangsangan nyeri yang diberikan. Efek analgetik dari kelompok kontrol positif 
terlihat efektif mulai dari menit ke-30 sampai akhir pengujian yaitu pada menit ke-120.

Dapat dilihat dari data yang diperoleh pada kelompok perlakuan ekstrak nanopartikel rimpang jahe merah bahwa efek yang ditimbulkan oleh $\mathrm{Kp}_{1}$ (dosis 0,0215 $\mathrm{g} / \mathrm{kgBB}$ ) tidak lebih baik dari parasetamol 0,132 gram dalam mengurangi rasa nyeri pada tikus yang diinduksi secara termik menggunakan waterbath, tetapi pada $\mathrm{Kp}_{2}$ (dosis $0,043 \mathrm{~g} / \mathrm{kgBB})$ dan $\mathrm{Kp}_{3}$ (dosis 0,086 $\mathrm{g} / \mathrm{kgBB}$ ) mempunyai efek analgetik yang lebih baik dari parasetamol terutama $\mathrm{Kp}_{3}$ yang merupakan dosis maksimum pada penelitian ini. Hal ini disebabkan karena ekstrak yang digunakan adalah ekstrak nanopartikel dimana nanopartikel sendiri memiliki kelebihan kemampuan untuk menembus dinding sel yang lebih tinggi (Kawashima, 2000), yang berarti efektivitas yang dihasilkan oleh ekstrak lebih baik.

$\mathrm{Kp}_{1}$ (dosis $\left.0,0215 \mathrm{~g} / \mathrm{kgBB}\right)$ terlihat efek analgetiknya mulai dari menit ke-30 setelah perlakuan dan tetap memperlihatkan efek analgetiknya sampai dengan menit ke120. $\mathrm{Kp}_{2}$ (dosis $\left.0,043 \mathrm{~g} / \mathrm{kgBB}\right)$ terlihat efek analgetiknya mulai dari menit ke-30 setelah perlakuan dan tetap memperlihatkan efek analgetiknya sampai dengan menit ke-120. $\mathrm{Kp}_{3} \quad$ (dosis $0,086 \mathrm{~g} / \mathrm{kgBB}$ ) terlihat efek analgetiknya mulai dari menit ke-30 setelah perlakuan dan tetap memperlihatkan efek analgetiknya sampai dengan menit ke-120.
Tanpa melihat perbedaan dosis nanopartikel ekstrak rimpang jahe merah yang diberikan, penelitian ini membuktikan bahwa secara farmakologis tanaman ini memiliki efek analgetik yang karena memiliki kandungan alkaloid dan flavonoid (Hernani dan Winarti, 2011). Alkaloid yang terkandung dalam tanaman ini mampu menghambat sintesis dan pelepasan leukotrin sehingga mengurangi rasa nyeri sedangkan flavonoid mampu menghambat enzim siklooksigenase (Suryanto, 2012). Dengan demikian akan mengurangi produksi prostaglandin oleh asam arakidonat sehingga mengurangi rasa nyeri (Gunawan, 2008).

Hasil analisis statistik uji ANOVA (tabel 2) rata-rata respon tikus kelompok kontrol negatif, kontrol positif, dan kelompok perlakuan menunjukkan hasil yang bermakna dengan nilai $\mathrm{p}=0,019(\mathrm{p}<0,05)$.

Berdasarkan pengamatan yang telah dilakukan pada tikus yang diinduksi secara termik menggunakan waterbath, dapat dilihat bahwa tidak semua tikus menunjukkan reaksi yang sama. Ketidaksamaan tersebut berupa lompatan atau hanya berupa jilatan atau keduanya dan jumlah respon tikus yang berbeda-beda sebelum perlakuan disebabkan oleh faktor yang mempengaruhi metabolisme obat atau ekstrak yang diberikan pada tikus, antara lain yaitu genetik atau keturunan, perbedaan umur, makanan dan penyakit (Coleman, 2010). 
Melihat banyaknya faktor yang dapat mempengaruhi, dapat disimpulkan bahwa adanya spesifitas individual terhadap induksi nyeri yang diberikan dan respon tikus terhadap pemberian obat dan ekstrak nanopartikel pun berbeda-beda, sehingga data pengamatan berbeda-beda setiap tikus walaupun dalam kelompok perlakuan yang sama, namun pada keseluruhan rata-rata hasil pengamatan ini menunjukkan respon sesuai dengan yang diharapkan dari masing-masing kelompok perlakuan.

\section{KESIMPULAN}

Berdasarkan hasil penelitian dapat disimpulkan bahwa nanopartikel ekstrak rimpang jahe merah dengan dosis 0,0215, 0,0043, dan 0,0086 memberikan efek analgetik pada tikus putih jantan galur wistar (Rattus norvegicus) dapat dilihat dari menurunnya respon tikus (jilatan dan lompatan) setelah diberikan nanopartikel eksrak rimpang jahe merah.

\section{SARAN}

Berdasarkan penelitian yang telah dilakukan, penulis menyarankan bahwa perlu dilakukan penelitian lebih lanjut tentang karakterisasi ukuran partikel ekstrak etanol rimpang jahe merah dan penggunaan metode lain dalam pembuatan nanopartikel.

\section{DAFTAR PUSTAKA}

Dugasani, S, Pichika, M.R, Nadarajah, V.D, Balijepalli M.K, Tandra S, dan Korlakunta J.N. 2010. Comparative antioxidant and anti-inflammatory effects of [6]-gingerol, [8]- gingerol, [10]-gingerol and [6]-shogaol. J.Ethnopharmacol. Elsavier Ireland.

Gunawan, S.G., Setiabudy, R., Nafrialdi, dan Elsyabeth. 2008. Farmakologi dan Terapi . Edisi Kelima. FKUI, Jakarta.

Guyton, A.C. 1994. Buku Ajar Fisiologi Kedokteran. Terjemahan K.A. Tengadi. EGC, Jakarta.

Hakim, L. 2002. Uji Farmakologi dan Toksikologi Obat Alam Pada Hewan Coba. Universitas Muhamadiyah, Purwokerto.

Hernani dan Winarti, C. 2011. Kandungan Bahan Aktif Jahe dan Pemanfaatannya dalam Bidang Kesehatan. Balai Besar Penelitian dan Pengembangan Pascapanen Pertanian, Bogor.

Kawashima, Y., Yamamoto, H., Takeuchi, H., dan Kuno, Y. 2000. Mucoadhesive DLlactide/glycolide Copolymer Nanospheres Coated with Chitosan to Improve Oral Delivery of Elcatonin. Pharmaceutical Development and Technology. 5:(1),77-85. 
Mohanraj, V.J., dan Y. Chen. 2006.

Nanoparticles: A Review. Tropical

Journal of Pharmaceutical Research.

5:(1), 561-573.

Sailaja, K.A., Amareshwar, P., dan

Chakravarty, P. 2010. Chitosan

Nanoparticles as a Drug Delivery

System. Research Journal of

Pharmaceutical, Biological and

Chemical.

Suryanto, E. 2012. Fitokimia Antioksidan.

Putra Media Nusantara, Surabaya.

Tim Lentera. 2002. Khasiat dan Manfaat

Jahe Merah : Si Rimpang Ajaib.

Agromedia Pustaka, Jakarta.

Tiyaboonchai, W. 2003. Chitosan

Nanoparticles: Apromising System For

Drug Delivery. Naresuan University

Journal. 11:(3),51-6.

Turner, R. A. 1965. Screening Methods in Pharmacology. Academic Press, New York.

Zhang, Y.Q., Tao, M.L., Shen, W.D., Zhou, Y.Z., Ma, .Y., dan Zhou, W.L. 2004. Immobillization of L-asparaginase on the Microparticles of the Natural Silk Sericin Protein and its Characters. Biomaterials. 25:(4),3751-3759. 